Róża Milic-Czerniak*

\title{
Rola fintechów w rozwoju innowacji finansowych
}

The role of FinTechs in growth of financial innovation: This paper looks at the role of financial technology (FinTech). So-called FinTech is an innovation that aims to compete with traditional financial methods of delivery of financial services. The article begins with a brief discussion concerning the definition of innovation. Next, the author describes the main types of FinTech companies and segments of services which implement FinTech innovations and technologies. Particular attention is given to the role of companies related to payment cards in Poland, mostly in the process of diffusion and infusion of this payment instrument. It is highlighted that payment card innovations extend the life cycle of the product.

Słowa kluczowe: fintech, innowacja, karty płatnicze, big data, analityka zaawansowana Keywords: FinTech, innovation, payment cards, Big Data, advanced analysis

* Doktor hab. nauk ekonomicznych, profesor Uczelni Techniczno-Handlowej wWarszawie; e-mail: r.milic.czerniak@gmail.com.

\section{Wstęp}

Polska nie należy do krajów bardzo innowacyjnych. W 2017 r. została zakwalifikowana w Europejskim Rankingu Innowacyjności (European Innovation Scoreboard) do grupy „umiarkowanych innowatorów”. Uplasowała się na 25. miejscu wśród 28 państw, wyprzedzając jedynie Rumunię, Bułgarię i Chorwację. O niewysokiej innowacyjności Polski świadczy także relatywnie niski poziom nakładów na działalność badawczo-rozwojową $(\mathrm{B}+\mathrm{R})$, który w 2017 r. wynosił tylko 1,04\% PKB (podczas gdy u lidera UE - Szwecji 3,25\%, a u lidera UE-12 - w Czechach 1,68\%). Zgodnie ze strategią „Europa 2020”, której jednym z priorytetów jest intensyfikacja działalności B+R, Komisja Europejska chce podnieść do 2020 r. poziom inwestycji w badania i rozwój średnio do 
3\% PKB krajów UE, a w Polsce powinien on wzrosnąć do poziomu co najmniej $1,7 \% \mathrm{PKB}^{1}$.

Za szczególnie innowacyjny zarówno w świecie, jak i w Polsce uważany jest sektor fintech, w którym funkcjonują firmy dostarczające rozwiązań technologicznych wspierających usługi finansowe. Jest to jedna z najszybciej rozwijających się branż technologicznych - wartość inwestycji w spółki fintech na świecie jeszcze w 2010 r. wynosiła 2 mld dolarów US, a w roku 2015 było to już ponad 15,5 mld dolarów² . Prognozowany globalny poziom inwestycji w spółki należące do tego sektora do 2020 r. może przekroczyć 130 mld euro.

Polska jest uznawana za regionalnego lidera technologicznego, oferującego w ramach fintech pionierskie rozwiązania dla sektora finansowego. Na Polskę przypada prawie 40\% wartości rynku fintech w Europie Środkowo-Wschodniej (oszacowanego na 2,2 mld euro), na Austrię 27\%, a na znajdującą się na trzeciej pozycji Republikę Czeską już tylko 9\% ${ }^{3}$. Szczególne osiągnięcia zaobserwować można we wdrażaniu innowacyjnych płatności detalicznych, przez co polskie banki są stawiane bankom w innych krajach za wzór ${ }^{4}$.

W artykule zostaną pokazane na tle charakterystyki sektora fintech zmiany w rozwoju innowacji związanych z kartami płatniczymi w Polsce. Opisana będzie rola, jaką odgrywają firmy fintech w procesie dyfuzji oraz infuzji tego instrumentu płatniczego. Innowacje kart płatniczych wydłużają cykl życia tego produktu, wplatając go w nurt najnowocześniejszych instrumentów płatniczych: zbliżeniowych, mobilnych oraz internetowych.

Karty płatnicze stały się najważniejszym instrumentem płatniczym w obrocie bezgotówkowym w Polsce. Ponadto były i nadal są postrzegane jako jeden z nowoczesnych sposobów regulowania płatności, gdyż innowacje wpływają na zmianę sposobów ich użytkowania (są wygodniejsze, szybsze, tańsze), przez co przestały być elitarnym instrumentem dla najzamożniejszych, a stają się przydatne w życiu codziennym dla coraz szerszego grona konsumentów przy dokonywaniu płatności powszechnych, o niskich kwotach. Umożliwiły przełamanie barier przestrzennych i czasowych związanych z dostępem do własnych środków pieniężnych.

1 European Innovation Scoreboard 2018, European Union, Luxembourg 2018, https:// www.interregeurope.eu/policylearning/news/3806/european-innovation-scoreboard-2018/ [dostęp: 28 listopada 2018 r.].

2 The Future of FinTech and Banking. Digitally disrupted or reimagined?, Report Accenture, https://bluemedia.pl/pressroom/raporty/future-fintech-and-banking-raport-accenture [dostęp: 20 sierpnia 2018 r.].

3 CEE FinTech Report, Deloitte 2016, https://itreseller.com.pl/rynek-fintech-technologie-dla-uslug-finansowych-w-europie-srodkowo-wschodniej-jest-wart-22-mld-euro-cee-fintech-report-deloitte/ [dostęp: 21 sierpnia 2018 r.].

${ }^{4}$ A. Kühner, Was deutsche Institute von Banken im Ausland lernen können, „Bankmagazin" 2016, nr 6. 


\section{Innowacje produktów finansowych - pojęcia i rodzaje}

W literaturze przedmiotu spotkać można bardzo różne definicje pojęcia „innowacje”. Na szczególną uwagę zasługują definicje J. Schumpetera, który wprowadził ten termin na grunt ekonomii, oraz E.M. Rogersa, klasyka teorii innowacji. Większość późniejszych definicji jest zbieżnych z tymi dwoma podejściami. $\mathrm{W}$ ujęciu Schumpetera innowacja oznacza wprowadzanie do praktyki nowego rozwiązania ${ }^{5}$. Dla E.M. Rogersa natomiast innowacją jest idea, procedura postępowania lub przedmiot, który jest postrzegany jako nowy przez osobę lub inną jednostkę adaptującą innowację . Autorzy tych definicji podkreślają z jednej strony, iż chodzi o pewną nowość, z drugiej strony jednak koncentrują się na dwóch odmiennych, niemniej istotnych, etapach jej wdrażania, począwszy od pierwszego wdrożenia innowacji, rozpoczynającego jej dyfuzję, aż po jej docieranie do coraz szerszego kręgu odbiorców (infuzję).

Proces rozpowszechniania innowacji nie jest bowiem jednorodny. Zwraca na to uwagę A.H. Jasiński, podkreślając, że pojawienie się nowego produktu na rynku rozpoczyna proces dyfuzji innowacji (produktowej), który można rozumieć dwojako, a mianowicie jako „dyfuzję po stronie nabywców i jako dyfuzję po stronie dostawców"7. W celu odróżnienia tych dwóch równoległych procesów w upowszechnianiu innowacji będziemy stosować w dalszej części artykułu pojęcie dyfuzji oraz infuzji innowacji.

Dyfuzja innowacji, czyli, używając języka Schumpetera, proces masowego wystąpienia imitatorów rozwiązań innowacyjnych, obejmuje stronę podażową wdrażania innowacji i jest kluczowy, gdyż podaż przedsiębiorcy innowatora nie jest w stanie wpłynąć istotnie na zmianę sytuacji gospodarczej nawet w przypadku innowacji przełomowej.

Proces infuzji (absorbcji) innowacji, a więc popularyzacji nowego produktu, usługi itd., polega natomiast na umiejętnym docieraniu z nowością do jej odbiorców - zgodnie z założeniem, że to nie wynalazki zmieniają świat, lecz ich zastosowanie - obejmuje on stronę popytową innowacji. Im większej populacji potencjalnych odbiorców (klientów) dotyczy, tym można mówić o większym sukcesie wdrażania danej innowacji. Proces ten jest zbieżny zatem $\mathrm{z}$ rozumieniem dyfuzji innowacji przez E.M. Rogersa, który w swojej prekursorskiej pracy traktuje ją jako proces, podczas którego innowacja jest prezentowana przez określone kanały komunikacyjne (w raczej długim okresie) członkom systemu społecznego. Jest to dla niego specjalny system

5 J. Schumpeter, Teoria rozwoju gospodarczego, PWN, Warszawa 1960, s. 322.

6 E.M. Rogers, Diffusion of innovations, Free Press Collier-Macmillan, New York 1983, s. 11 .

7 A.H. Jasiński, Model procesowy innowacji: ramy teoretyczne [w:] Innowacje w zarządzaniu, red. J. Skalik, A. Zabłocka-Kluczka, seria „Prace Naukowe Uniwersytetu Ekonomicznego we Wrocławiu", Wrocław 2013, s. 74. 
komunikacji, w którym informacja dotyczy nowych pomysłów ${ }^{8}$. Właśnie ta definicja jest wykorzystywana często w marketingu odnośnie do prawidłowego upowszechniania na rynku nowego produktu. Dla przykładu guru marketingu P. Kotler definiuje innowację jako: jakiekolwiek dobro, usługa, pomyst, który jest postrzegany przez kogoś jako now $y^{9}$, zalecając odmienne korzystanie w tej sytuacji z instrumentów promocji, a przede wszystkim podkreślając konieczność dostosowania procesu komunikacji do klientów nieznających danego produktu i jego właściwości.

W różnych kategoryzacjach innowacji na szczególną uwagę zasługuje istotność nowości czy ulepszeń. $Z$ tego punktu widzenia można wyodrębnić innowacje: przełomowe (radykalne, wielkie, kreatywne, zasadnicze); przyrostowe (incremental, średnie), modyfikujące wynalazek przełomowy; drobne; a także pozorne, polegające na drobnych zmianach. Komitet do spraw Rozliczeń i Rozrachunku Płatności przy Banku Rozrachunków Międzynarodowych w Bazylei, traktując innowacje w płatnościach detalicznych jako nowy lub znacznie ulepszony instrument, rozwiązanie lub schemat, które osiągnęły znaczny udział w rynku lub mające taki potencjał ${ }^{10}$, stawia w zasadzie znak równości pomiędzy innowacjami radykalnymi i przyrostowymi. Upoważnia tym samym do pomijania określeń szczegółowych (przełomowe, przyrostowe) przy omawianiu innowacji.

W definicjach innowacji finansowej nie tylko podkreśla się, że mamy do czynienia z nowością, ale również zwraca uwagę na to, iż owo novum ma wpłynąć na redukcję kosztów, ograniczanie ryzyka lub dostarczanie ulepszonego produktu, usługi, procesu, instrumentu lepiej zaspokajającego potrzeby i preferencje uczestników rynku finansowego ${ }^{11}$.

Innowacje technologiczne zmieniają całą gospodarkę, w tym także sektor usług finansowych. Innowacja finansowa nazywana w ostatnich latach terminem „fintech” stała się wiodącym czynnikiem transformacji sektora finansowego w skali globalnej. Zmiany technologiczne stwarzają szanse rozwoju zarówno dla nowych podmiotów (start-upy fintech), jak i dla dojrzałych instytucji (np. tradycyjnych banków), pozwalając obniżyć koszty, zwiększyć zasięg czy wykreować nowe modele biznesowe, a przede wszystkim wzbogacić pozytywne doświadczenia klientów w trakcie zaspokajania potrzeb finansowych.

E.M. Rogers, Diffusion of innovations, op. cit.

9 P. Kotler, Marketing. Analiza. Planowanie. Wdrażanie i kontrola, Gebethner i S-ka, Warszawa 1994, s. 322.

${ }^{10}$ Innovation in Retail Payments, Report of the Working Group on Innovation in Retail Payments, Committee on Payment and Settlement Systems, BIS, May 2012, s. 4.

11 W.S. Frame, L.J. White, Empirical Studies of Financial Innovation: Lots of Talk, Little Action?, Federal Reserve of Atlanta, Working Paper 6/2002. 


\section{Fintech jako podmiot uczestniczący w procesie implementacji innowacji}

Termin fintech (FinTech) stał się popularnym, międzynarodowym skrótem określenia Financial Technology (technologia finansowa), a więc innowacyjnych usług finansowych opartych na technologii ICT (Information-Communication Technology), dla sektora finansowego oraz dla klientów tego sektora. Komitet Bazylejski zaproponował traktowanie fintechów jako: technologicznych innowacji finansowych, których efektem sa nowe modele biznesowe, aplikacje, procesy lub produkty, mające istotny materialny wpływ na pracę rynków finansowych $i$ instytucji oraz świadczenie usług finansowych ${ }^{12}$. Głównym celem technologii finansowych oferowanych przez podmioty $z$ tego sektora jest poprawa efektywności i dostępności usług finansowych, zarówno z perspektywy klienta, jak i instytucji finansowej.

Do sektora fintechów zalicza się bardzo zróżnicowane podmioty, a najczęściej:

- giganty technologii znane pod akronimem GAFA, którymi są Google, Apple, Facebook oraz Amazon, które współpracują z bankami tradycyjnymi, dostarczając im aplikacje do płatności mobilnych (m.in. Google Pay, Apple Pay),

- nowoczesne banki wirtualne (tzw. neobanki), jak znajdujące się wśród największych fintechów Nubank z Brazylii, Atom Bank z Wielkiej Brytanii czy Revolut. Błyskawiczny rozwój tego ostatniego jest niezmiernie interesujący. Powstał on w Wielkiej Brytanii w 2015 r. początkowo jako platforma wymiany walut, a w 2018 r. otrzymał licencję Banku Litwy (dzięki czemu jego depozyty są objęte na Litwie gwarancją do 100 tys. euro), który umożliwia użytkownikom m.in. transfer i płatności w różnych walutach (także w kryptowalutach) bez opłat za używanie kart przedpłaconych i aplikacji mobilnych. W ciągu trzech lat działalności zdobył 3 mln użytkowników (przy liczbie mieszkańców Litwy 2,8 mln w 2017 r.). Codziennie otwiera 8-10 tys. nowych kont, a jego obroty wynoszą 4 mld dolarów US miesięcznie. Zamierza zdobyć $100 \mathrm{mln}$ klientów w najbliższych pięciu latach. Revolut planuje rozszerzenie oferty o produkty depozytowe, pożyczki konsumenckie oraz platformę do bezprowizyjnego inwestowania w akcje. Jest on najszybciej rosnącym fintechem również w Polsce, a w zamierzeniach jego zarządu jest, by stał się także najbardziej popularną aplikacją bankową w Polsce, umożliwiającą również zaciągnięcie pożyczki w ciągu kwadransa, po konkurencyjnych kosztach dla klienta ${ }^{13}$,

12 Sound Practices. Implications of fintech developments for banks and bank supervisors, Basel Committee on Banking Supervision, February 2018, https://www.bis.org/bcbs/publ/ d431.pdf [dostęp: 4 grudnia 2018 r.].

13 Revolut uzyskał europejską licencję bankowa, zaoferuje depozyty i pożyczki, https:// prnews.pl/revolut-uzyskal-europejska-licencje-bankowa-zaoferuje-depozyty-pozyczki-439481?smclient=fccada31-ad96-11e6-8101-0cc47a1256ac\&utm_source=salesmanago\& utm_medium=email\&utm_campaign=nlt_bnk_prnewspl [dostęp: 13 grudnia 2018 r.]. 
- podmioty oferujące kilka usług finansowych (tzw. multifintechy), operujące najczęściej na rynku płatności wirtualnych, mobilnych oraz kartami płatniczymi czy też na rynku pożyczek krótkoterminowych. Największe z nich, jak Ant Financial Services Group, Grab oraz DuXiaoma, funkcjonują na rynkach azjatyckich, dostarczając usług osobom wykluczonym finansowo. Ant Financial jest przy tym firmą fintech o najwyższej wartości w świecie (150 mld dolarów US), do 2014 r. znaną jako Alipay (spółka stowarzyszona Alibaba Group),

- podmioty wyspecjalizowane w świadczeniu wąskiego zakresu usług, jak Robinhood, oferujący aplikacje do obrotu akcjami spółek giełdowych, ETF-ami, opcjami i kryptowalutami. Niejednokrotnie są to start-upy, które rozpoczynają swoją działalność od najprostszej oferty jednego produktu.

Najwięcej ze 100 wiodących fintechów zdiagnozowanych w 2018 r. w badaniach KPMG znajdowało się w USA (18), Wielkiej Brytanii (12), Chinach (11), Australii (7) oraz Singapurze (6) i Niemczech $(4)^{14}$. W pierwszych pięciu państwach powstała zatem ponad połowa największych podmiotów fintech (54\%). Natomiast wśród 10 dominujących firm fintech znalazły się w 2018 r. głównie podmioty z Chin (4) oraz USA (3), podczas gdy Europę reprezentował tylko jeden fintech (tabela 1).

Struktura podmiotowa sektora fintech w Polsce jest inna niż w krajach o największej ich liczbie. W Polsce nie powstał żaden spośród 100 wiodących podmiotów fintech (a powstał np. na Litwie i w Czechach), ale również żaden neobank. Polskie fintechy to raczej małe, wyspecjalizowane firmy lub też multifintechy, koncentrujące się na rozwoju innowacji niewielu produktów. $\mathrm{Na}$ mapie podmiotów fintech w Polsce zlokalizowano firmy fintech (106), projekty fintechowe prowadzone przez tradycyjne instytucje (26 projektów), kantory internetowe (12), serwisy crowdfundingowe (13) oraz firmy pożyczkowe $(10)^{15}$.

Jako prekursorów i liderów polskich fintechów wymienia się Blue Media i PayU. Firmy te przez lata stanowiły o polskim sektorze fintechów w obszarze płatności, nawet jeszcze wtedy, gdy to pojęcie nie było znane. PayU SA jest przy tym pierwszą firmą, która uzyskała status krajowej instytucji płatniczej, a ponadto staje się podmiotem międzynarodowym (rozwija biznes płatniczy w regionie Europy Środkowo-Wschodniej). Obie firmy oferują innowacyjne produkty płatnicze bankom, handlowcom w sferze e-commerce oraz klientom detalicznym. Dzięki nim w Polsce pojawiły się przelewy natychmiastowe, transakcje typu pay-by-link, portfele elektroniczne, a także pożyczki społecznościowe. Wśród najważniejszych fintechów działających w Polsce wymienia się jeszcze

${ }^{14}$ Leading Global Fintech Innovators, FinTech100, Report KPMG, 2018, https://h2.vc/ wp-content/uploads/2018/11/Fintech100-2018-Report_Final_22-11-18sm.pdf [dostęp: 25 listopada 2018 r.].

${ }_{15}$ Mapa polskiego FinTechu 2018, Cashless, Fundacja FinTech Poland, Accenture, https://www.cashless.pl/system/uploads/ckeditor/attachments/1908/Mapa_Polskiego_Fintechu_2018.pdf [dostęp: 10 grudnia 2018 r.]. 


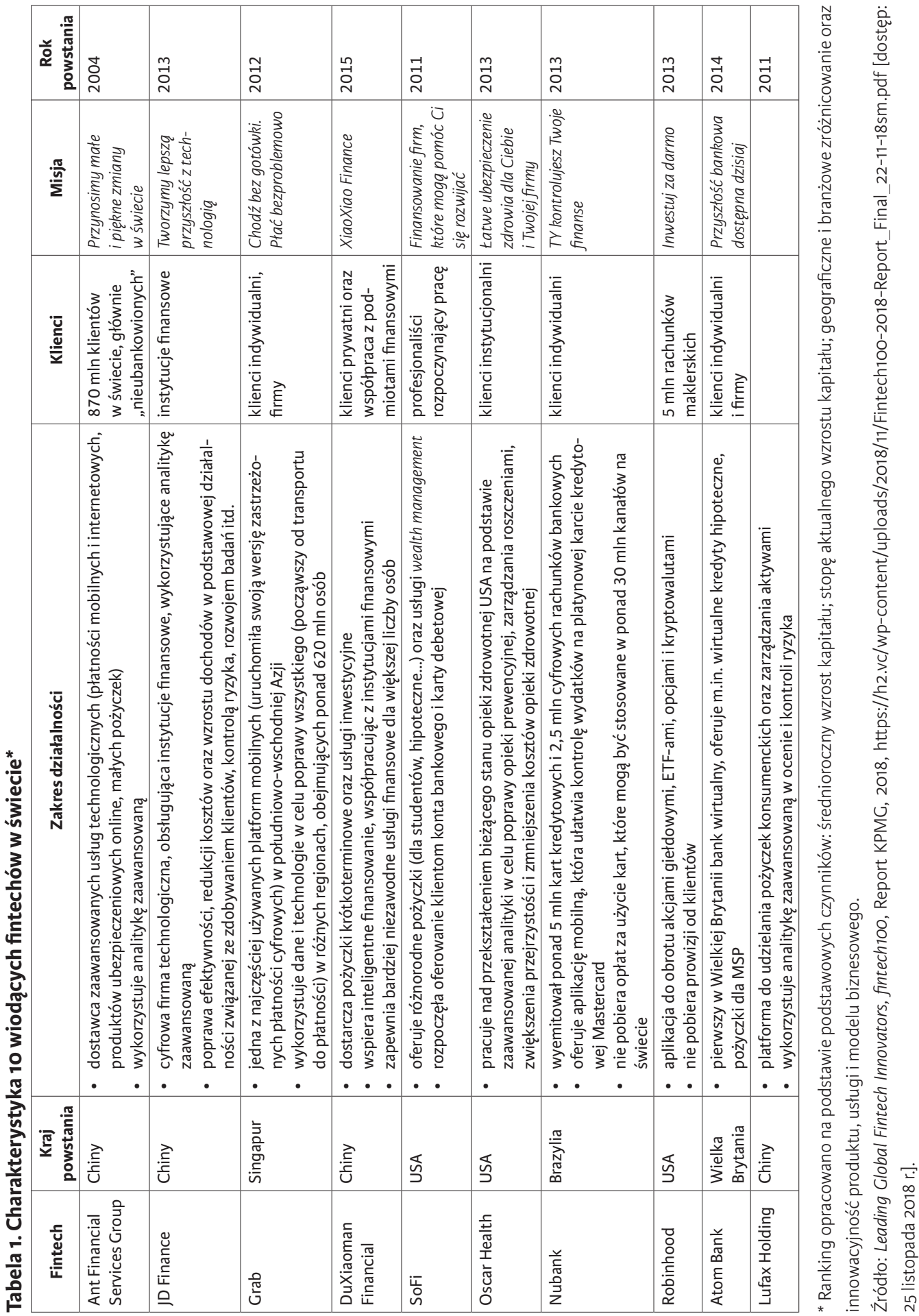


m.in. firmy Polish Payment Standard - Polski Standard Płatności (Blik), CurrencyOne, Finanteq, VoicePIN oraz ZenCard. System Blik oferowany przez Polski Standard Płatności stanowi przykład inicjatywy międzybankowej mającej na celu systemowe wykreowanie innowacji finansowej w skali całego sektora. Jego znaczenie na rynku płatności jest coraz większe.

W rozwoju polskiego rynku fintech ważną rolę odgrywają banki, podmioty międzybankowe i inne instytucje finansowe. Znaczna część innowacji i ich implementacji dokonuje się w dużych, dojrzałych instytucjach ${ }^{16}$. Powinny one stawać się w coraz większym stopniu platformami wielostronnymi, oferującymi różnorodne, innowacyjne produkty różnych typów fintechów. Należy je traktować jako nieuchronną strategię rozwoju instytucji finansowych w sytuacji, gdy podmioty zewnętrzne wprowadzają innowacyjne substytuty ich produktów. W niektórych branżach część platform osiągnęła wyższą wartość niż firmy oferujące wyłącznie własne produkty i usługi (np. światowy lider wynajmu nieruchomości platforma Airbnb jest obecnie wyżej wyceniana niż sieć hoteli Marriott) ${ }^{17}$.

Elementami przewagi konkurencyjnej firm z branży fintech są oprócz innowacyjnych produktów także uproszczone procedury, relatywnie niskie prowizje i opłaty, nowoczesne rozwiązania technologiczne (np. analityka zaawansowana) i marketingowe (np. orientacja na klienta, której podstawą jest kreowanie pozytywnych doświadczeń konsumentów) wykorzystywane w kompleksowej obsłudze klientów. Do szybkiej infuzji potencjału nowych rozwiązań niezbędna jest jednak odpowiednia skala biznesu oraz zaufanie konsumentów, a więc to, czym dysponują banki. Banki tradycyjne dostrzegają obecnie potrzebę współpracy przy wdrażaniu innowacji technologicznych, a jako najważniejsze ich źródło wymieniają fintech start-upy (72\%), technologicznych gigantów (53\%), pracowników banku (36\%), inne instytucje finansowe - aktualnych konkurentów (20\%) oraz instytucje finansowe, niebędące konkurentami ${ }^{18}$.

Zaufanie, a więc oczekiwanie wiarygodności słowa, obietnicy, ustnego lub pisemnego przyrzeczenia innej jednostki lub grupy, jest tym istotniejsze w przypadku sektora fintech, że funkcjonuje on głównie w świecie wirtualnym. Stąd na zaufanie do podmiotów fintech w istotny sposób wpływają, co oczywiste, dotychczasowe doświadczenia konsumentów ze współpracy z nimi. Pozytywne doświadczenia przekładają się na nieco wyższe zaufanie klientów do podmiotów fintech (56\%) niż do podmiotów tradycyjnych $(53 \%)^{19}$. Stanowi to istotny

\section{Ibidem.}

17 A. Hagiu, E.J. Altman, Jak stworzyć platformę na bazie własnego produktu, „Harvard Business Review Polska" kwiecień 2018, s. 89 i n.

18 Forging the future. How financial institutions are embracing fintech to evolve and grow, KPMG, November 2017, https://assets.kpmg.com/content/dam/kpmg/xx/pdf/2017/10/ forging-the-future-global-fintech-study.pdf [dostęp: 10 grudnia 2018 r.].

19 K. Świeszczak, Zaufanie w świecie finansów w obliczu rozwoju technologii na przykładzie banków i sektora FinTech, „Bezpieczny Bank” 2017, nr 2. 
element ryzyka dla banków i jest tym bardziej ważne, że ponad 26\% nabywców produktów i usług bankowych współpracowało w 2016 r. z sektorem fintech, ale tylko 2,9\% respondentów współpracowało wyłącznie z nim ${ }^{20}$.

Zasadą firm fintech jest wprowadzanie innowacji technologicznych raczej $\mathrm{z}$ zewnątrz do wewnątrz niż z wewnątrz na zewnątrz. Oznacza to, że zmiany innowacyjne są podporządkowane przede wszystkim usuwaniu negatywnych oraz kreowaniu pozytywnych doświadczeń klientów, powstających w trakcie korzystania z usług firmy. Innowacje są niejednokrotnie efektem współtworzenia ich z klientami, a także z innymi interesariuszami. Koncepcja współtworzenia polega na wprowadzaniu do współpracy przy tworzeniu nowych produktów wszystkich zainteresowanych grup interesariuszy, nie tylko zatem pracowników, lecz również klientów, dostawców itd. Celem takiego działania jest uwzględnianie interesów wszystkich grup interesariuszy przy ich aktywnym uczestnictwie, co jednocześnie znakomicie buduje zaufanie do instytucji i zachęca do korzystania $\mathrm{z}$ jej oferty ${ }^{21}$.

\section{Zakres działalności fintechów}

Lawinowe powstawanie podmiotów fintech jest często odpowiedzią na luki powstałe $\mathrm{w}$ ofercie produktowej i usługach świadczonych przez tradycyjne podmioty finansowe, które w niewystarczający sposób modernizowały swoją infrastrukturę i odpowiadały na zmieniające się potrzeby i oczekiwania klientów. Wielu konsumentów oczekuje od instytucji finansowych szybkiego dostosowywania produktów do ich indywidualnych potrzeb, podobnie jak się to dzieje w innych sektorach. Personalizacja usług, jak pokazały wyniki badań przeprowadzonych w 2017 r., jest najbardziej widocznym trendem zachowań konsumentów - w kolejnych dwóch latach wzrastały oczekiwania prawie co trzeciego respondenta na indywidualne traktowanie $(29 \%)^{22}$. Źródłem zmian w oczekiwaniach klientów są często doświadczenia wynikające z korzystania $\mathrm{z}$ usług poza sektorem finansowym. Nowoczesne firmy (takie jak Uber czy Netflix) personalizują obsługę klientów, wykorzystując zaawansowaną analitykę opartą na big data (BD), sztucznej inteligencji (Artificial Intelligence, AI) i kognitywnym myśleniu. Konsumenci oczekują zatem tego samego od każdego usługodawcy (a w tym i instytucji finansowych).

Rozwiązania fintechów obejmują wiele różnorodnych innowacji zarówno dla bankowości, ubezpieczeń, zarządzania aktywami i rynków kapitałowych, pozyskiwania kapitału, jak i dla finansów osobistych, płatności, pozyskiwania

${ }^{20}$ Badaniem objęto ponad 8000 respondentów (osób korzystających z produktów i usług finansowych) z 15 państw, World FinTech Report 2017, Capgemini \& LinkedIn \& Efma, s. 13.

${ }^{21}$ C.K. Prahalad, V. Ramaswamy, Przyszłość konkurencji, PWE, Warszawa 2005, s. 31.

22 Top of Mind Survey 2017, KPMG, https://home.kpmg.com/xx/en/home/insights/2017/06/top-of-mind-survey-2017.html [dostęp: 24 listopada 2018 r.]. 
i przechowywania danych i ich analityki, cyberbezpieczeństwa oraz pozostałych technologii. Biorąc pod uwagę przedmiot innowacji, najkorzystniej pogrupować je w pięć podstawowych segmentów, którymi są: finansowanie, zarządzanie aktywami, płatności, ubezpieczenia oraz analityka zaawansowana. Najliczniej podmioty fintech funkcjonują na rynku płatności oraz finansowania (głównie klientów indywidualnych oraz małych i średnich firm).

Schemat 1. Segmenty usług branży fintech

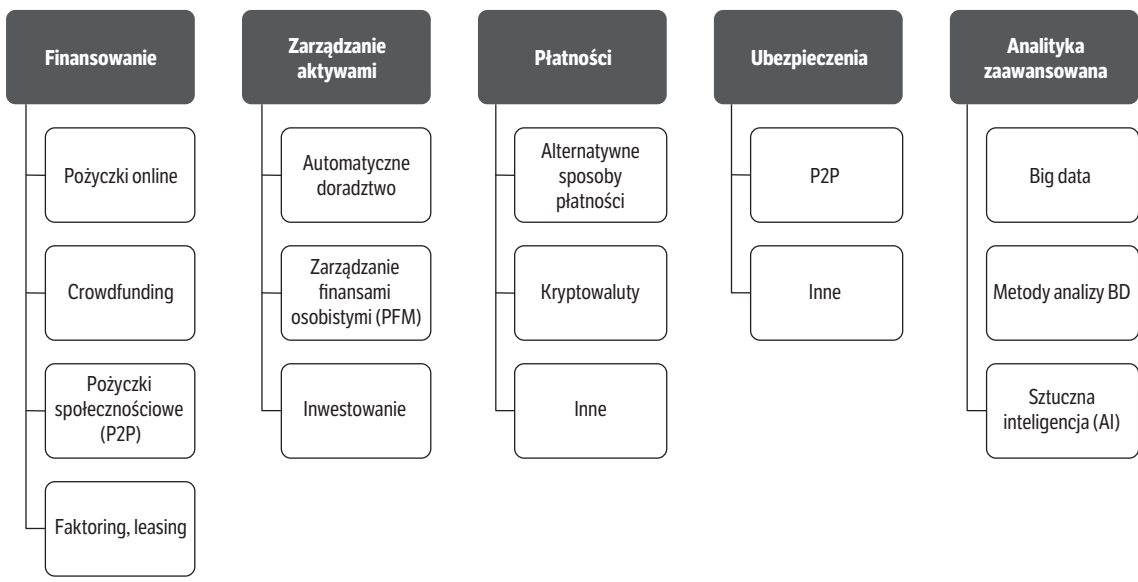

Szerokie zainteresowanie firm fintech rynkiem usług płatniczych wynika przede wszystkim z zaniedbania jego rozwoju przez banki, dominującego podmiotu po stronie podaży. Banki traktowały te usługi jako niekonkurencyjne (także ze względu na ograniczenia regulacyjne), niskodochodowe, raczej jako usługi transakcyjne lub też tanie źródło finansowania akcji kredytowej. Konsekwencją była niska efektywność rynku płatności, jak też niewielka ich innowacyjność $\mathrm{w}$ tym zakresie ${ }^{23}$. Prowadziło to $\mathrm{z}$ jednej strony do coraz większego rozdźwięku między prywatnym a społecznym kosztem funkcjonowania instrumentów płatniczych, zaniedbania rozwoju obrotu bezgotówkowego, a z drugiej strony do coraz większego niezadowolenia klientów z dysproporcji między ich oczekiwaniami a standardem realizacji potrzeb w zakresie dostępu do swoich środków finansowych.

Innowacje dotyczące instrumentów i metod płatności są wyjątkowo liczne, a ich efekt określany jest jako alternatywne sposoby płatności. W samym tylko 2010 r. w przeglądzie przeprowadzonym przez Bank Światowy (z udziałem

${ }^{23}$ J. Harasim, Współczesny rynek płatności detalicznych - specyfika, regulacje, innowacje, Uniwersytet Ekonomiczny, Katowice 2013, s. 17-24. 
101 banków centralnych) zidentyfikowano 173 innowacje ${ }^{24}$. Bank Rozrachunków Międzynarodowych wyodrębnił pięć rodzajów innowacji produktowych w tym obszarze, a mianowicie innowacje związane z kartami płatniczymi, płatności internetowe (np. pay-by-link), płatności mobilne, elektroniczną prezentację i płatności rachunków (electronic bill presentment and payment), a także innowacje związane z poprawą infrastruktury i bezpieczeństwa płatności. Zajmuje się nimi ok. $40 \%$ firm fintech. Należy dodać do nich również coraz częściej pojawiające się płatności kryptowalutami, obejmujące usługi związane z płatnościami, gromadzeniem, używaniem i wymianą kryptowalut (waluty wirtualne, takie jak bitcoin i ok. 1000 innych, stanowią alternatywę dla walut oficjalnych). Do zabezpieczenia transakcji elektronicznych kryptowalutami wykorzystywany jest najczęściej blockchain.

W sukurs dalszemu, intensywnemu rozwojowi segmentu płatności fintech przychodzą regulacje prawne, a głównie implementacja dyrektywy o usługach płatniczych (Payments Services Directive 2, PSD2) ${ }^{25}$, która czyni bardziej dostępnym rynek usług płatniczych, ograniczając monopol banków. Wprowadza ona m.in. pojęcie instytucji trzeciej (która będzie mogła zainicjować usługę płatności oraz uzyskać dostęp do informacji o rachunku klienta) ${ }^{26}$, a także tzw. małej instytucji płatniczej (MIP) ${ }^{27}$, która będzie mogła świadczyć usługi płatnicze, nie spełniając dosyć wygórowanych warunków, jakie muszą spełniać krajowe instytucje płatnicze.

Drugim co do wielkości segmentem usług oferowanych przez firmy fintech jest finansowanie, w obrębie którego udzielane są pożyczki online, pożyczki społecznościowe, crowdfunding, a także usługi w zakresie faktoringu (również faktoringu odwróconego) oraz leasingu. Sprzedaż innowacyjnych produktów pożyczkowych przez internet współwystępuje często z procesem wideoweryfikacji osoby składającej wniosek, wykorzystywaniem social scoringu itd. Pożyczki, podobnie jak faktoring oraz leasing, skierowane są przy tym głównie do klientów, którym trudno je otrzymać w bankach, a często są nimi firmy należące do kategorii małych i średnich przedsiębiorstw.

Pożyczki społecznościowe [social lending, P2P (peer-to-peer)] to transakcje finansowe zawierane bezpośrednio między osobami fizycznymi poprzez serwisy

${ }^{24}$ Payment System Worldwide - A Snaphot. Outcomes of the Global Payment System Survey 2010, „The World Bank” 2011, s. 44-45.

25 Dyrektywa Parlamentu Europejskiego i Rady (UE) 2015/2366 z 25 listopada 2015 r. w sprawie usług płatniczych w ramach rynku wewnętrznego, zmieniająca dyrektywy 2002/65/ WE, 2009/110/WE, 2013/36/UE i rozporządzenie (UE) nr 1093/2010 oraz uchylająca dyrektywę 2007/64/WE, OJ L 337, 23 grudnia 2015 r., s. 35-127.

${ }^{26}$ Szerzej na ten temat pisze W. Szpringer, Nowe technologie a sektor finansowy. Fintech jako szansa i zagrożenie, Poltext, Warszawa 2017, s. 124 i n.

${ }^{27}$ Licencję MIP może uzyskać spółka z ograniczoną odpowiedzialnością o kapitale zakładowym 5 tys. zł. Firmy te będą mogły wydawać instrumenty płatnicze (np. aplikacje mobilne) czy prowadzić rachunki, ale nie będą mogły wydawać pieniądza elektronicznego. 
internetowe. Stronami w tym przypadku są pożyczkobiorcy oraz inwestorzy. Transakcje tego typu są zawierane przy pomocy platform pożyczkowych, czyli serwisów internetowych obsługiwanych przez fintechy, których zadaniem jest pośrednictwo w procesie transakcji, a także weryfikacja potencjalnych pożyczkobiorców, zawarcie umowy oraz kontrola spłaty zobowiązania.

Pierwszy serwis tego typu był założony w Wielkiej Brytanii - „Zopa” (Zone of Possible Agreement). Pośredniczy rocznie przy udzielaniu pożyczek o wartości 200-300 mln funtów, zaś amerykański Lending Club udziela ich za niemal miliard dolarów ( $3 / 4$ wolumenu pożyczek społecznościowych na rynku amerykańskim). Chiński rynek pożyczek społecznościowych osiągnął w 2017 r. wartość 445 mld dolarów. Do 2025 r. ich globalny rynek ma osiągnąć wartość biliona dolarów. W Chinach liczba osób, które korzystały z platform pożyczek społecznościowych, przekroczyła 3,5 $\mathrm{mln}^{28}$.

W Polsce rynek pożyczek społecznościowych ma charakter niszowy - pod koniec 2017 r. jego wartość była szacowana na zaledwie ok. $100 \mathrm{mln}$ złotych. Otworzyła go w lutym 2008 r. firma Kokos.pl, która od stycznia 2018 r. przestała oferować pożyczki społecznościowe pochodzące od inwestorów prywatnych. Zamiast nich w ofercie znalazły się pożyczki pochodzące od firm pożyczkowych, gdyż inwestorzy indywidualni udostępniający swoje środki mogą (w myśl znowelizowanej ustawy o kredycie konsumenckim) zostać uznani za przedsiębiorców (jeśli działalność ma charakter powtarzalny), co pociąga za sobą konieczność ich rejestrowania się jako instytucji pożyczkowej lub też prowadzenia tzw. działalności nierejestrowej ${ }^{29}$.

Popularnym w niektórych państwach zachodnich stał się również crowdfunding, a więc finansowanie innowacji przez społeczności (crowd - tłum oraz funding - finansowanie). Polega on na tym, że pomysłodawca danego projektu prosi o wsparcie finansowe internautów, oferując w zamian określone korzyści (np. gotowy produkt lub zniżkę przy jego zakupie, gdy wejdzie już do sprzedaży). Gama finansowanych w ten sposób projektów jest szeroka - od gier komputerowych, przez rozmaite gadżety mobilne, po filmy science-fiction.

Crowdfunding rozpoczął się w latach 90. od branży muzycznej, a w $2000 \mathrm{r}$. został założony serwis ArtistShare.net, dzięki któremu artyści mogą zbierać pieniądze na projekty od swoich wielbicieli. W 2009 r. powstała platforma crowdfundingowa Kickstarter, która zasłynęła projektami z kategorii rozrywki

${ }_{28}$ Polskę ominą boom na pożyczki społecznościowe. W Chinach standardy pożyczania P2P nie nadązyly za popytem, https://prnews.pl/polske-ominal-boom-pozyczki-spolecznosciowe-chinach-standardy-pozyczania-p2p-nadazyly-popytem-438829 [dostęp: 21 listopada 2018 r.].

${ }^{29}$ Działalności nierejestrowa umożliwia osobom fizycznym, których przychód z tej działalności nie przekroczy w żadnym miesiącu 50\% kwoty minimalnego wynagrodzenia, i które w okresie ostatnich 60 miesięcy nie prowadziły działalności gospodarczej, angażowanie się w finansowanie społecznościowe bez konieczności ubiegania się o status firmy pożyczkowej. 
elektronicznej - na ponad 111 tys. udanych projektów 11 mln użytkowników tego portalu przeznaczyło ponad 2,5 mld dolarów.

W Polsce zidentyfikowano trzynaście platform crowdfundingowych (m.in. Wspieram.to oraz PolakPotrafi.pl), które, podobnie jak ich amerykańscy prekursorzy, oferują sporą gamę kategorii, w których można umieszczać swoje projekty. Wyniki są jednak nieznaczne - rekord wsparcia odnotował PolakPotrafi w wysokości ponad 385 tys. zł.

W segmencie usług firm fintech, określanym jako zarządzanie aktywami, na uwagę zasługują przede wszystkim aplikacje wspomagające zarządzanie budżetem domowym (Personal Finance Menager, PFM) oraz zautomatyzowane doradztwo finansowe (financial robo-advisor). Dzięki aplikacji PFM użytkownik otrzymuje rzeczywisty obraz swoich rachunków oszczędnościowych, inwestycyjnych, kredytowych oraz kart kredytowych. Analityczne moduły systemu dzielą także cały strumień wszystkich płatności na kategorie, podsumowują je i określają, ile wydano na czynsz, żywność, restauracje itd. (zaawansowana technologia kategoryzacji firmy Mint.com została nawet opatentowana). Serwis analizuje poszczególne wydatki i wskazuje w sposób spersonalizowany, na czym można zaoszczędzić, przypomina o konieczności nieprzekraczania budżetu, proponuje oszczędne warianty transakcji, a drogą e-mailową lub SMS-ową wysyła przypomnienia o płatnościach. W USA (od 1983 r.) aplikacje PFM są najczęściej integralną częścią bankowości elektronicznej, przez co wszystkie dane są sczytywane online z kont klienta i automatycznie kategoryzowane. Z flagowego produktu Quicken (fintechu Intuit) korzysta ponad $10 \mathrm{mln}$ gospodarstw domowych.

Aplikacje PFM oferowane są w Polsce zarówno przez podmioty niebankowe (od 2005 r.), takie jak np. iFin24, Kontomierz oraz Money Zoom, jak i banki, które udostępniają je od 2010 r. (Meritum Bank - Meritum Planner, a następnie Alior Bank - Menedżer Finansów, Millennium - Manager Finansów, ING Bank - Finansometr). Główną zaletą narzędzi PFM oferowanych przez banki jest wygoda korzystania z nich oraz bezpieczeństwo. Są one systematycznie modyfikowane po to, by użytkownicy otrzymywali jak najpełniejszy obraz swoich transakcji, a fintechy czy banki coraz więcej informacji o faktycznych zachowaniach konsumpcyjnych swoich klientów.

Algorytmy zautomatyzowanego doradztwa finansowego, jako ciągi określonych działań decyzyjnych (bez udziału człowieka), opartych na zestawach algorytmów dopasowanych do potrzeb i preferencji inwestora, wykorzystywane są do alokacji aktywów i konstrukcji portfeli inwestycyjnych. Automatyczne doradztwo, biorąc pod uwagę poziom zaawansowania algorytmów decyzyjnych, może mieć charakter informacyjny, wspomagający lub też decyzji samodzielnych ${ }^{30}$. Podmioty fintech wykorzystują $\mathrm{w}$ tym zakresie technologię machine

${ }^{30}$ A. Gospodarowicz, Bankowość elektroniczna. Istota i innowacje, C.H. Beck, Warszawa 2018, s. 102 i n. 
learning (uczenie maszynowe), czyli programy oparte na sztucznej inteligencji, umożliwiające zarządzanie portfelami inwestycyjnymi przez wirtualnych doradców.

Sektor ubezpieczeniowy, zaliczany do wiodących w świecie finansów, jest relatywnie powoli rozwijany przez firmy fintech, a główne obszary zainteresowania to wyspecjalizowane porównywarki ubezpieczeń oraz coraz popularniejsze ubezpieczenia społecznościowe ${ }^{31}$. Na polskim rynku technologii usprawniających działania branży ubezpieczeniowej (insurtech), podobnie jak i na rynku bankowym, funkcjonują zarówno podmioty trzecie świadczące usługi dla towarzystw ubezpieczeniowych, jak też realizowane są projekty zakładów ubezpieczeniowych [np. innowacyjna usługa PZU go, oparta na ,internecie rzeczy" - Internet of Things (IoT)], a także partnerstwa strategiczne z fintechami, w wyniku których powstała np. aplikacja Screenity czy platforma Play Ubezpieczenia. Dużą popularność zyskuje także pomysł wykorzystania społecznych sieci ubezpieczeń wzajemnych (np. wzajemne ubezpieczenia rowerów, sprzętu elektronicznego), których możliwość organizowania przez osoby fizyczne jest jednak znacznie ograniczona ze względów regulacyjnych ${ }^{32}$, a wszelkie inicjatywy oddolne zmuszone są do pozyskania parasola ochronnego w postaci już istniejących towarzystw ubezpieczeniowych.

Wyodrębnienie segmentu usług fintech $\mathrm{z}$ zakresu analityki zaawansowanej podyktowane było z jednej strony faktem, że stanowi ona zaplecze technologiczne wdrażania innowacji w wielu firmach fintech (druga "noga” fintech), a $z$ drugiej strony powstawaniem specjalistycznych firm oferujących te usługi. Analityka zaawansowana (3.0, oparta na Big Data) określana jest jako era produktów i usług wzbogaconych lub nowych dzięki danym. Charakteryzuje ją posługiwanie się efektywnymi metodami gromadzenia i analizowania danych nie tylko w odniesieniu do operacji firm, ale także w związku z tym, co oferują, wbudowując umiejętność wykorzystania danych w produkty i usługi nabywane przez klientów i tworząc dla nich inteligentne oferty produktowe.

Analityka zaawansowana wykorzystuje w swoich analizach nieuporządkowane dane płynące z rzeczywistego świata (online). Analityka BD obejmuje

${ }^{31}$ Fintech $w$ Polsce, bariery i szanse rozwoju, raport $U W$, http://fintechpoland.com/wp-content/uploads/2016/12/FinTech_w_Polsce_bariery_i_szanse_rozwoju.pdf, s. 23 [dostęp: 30 listopada 2018 r.].

32 Ustawa z 11 września 2015 r. o działalności ubezpieczeniowej i reasekuracyjnej stawia podmiotom zamierzającym prowadzić działalność ubezpieczeniową bardzo wysokie wymogi - zarówno formalne (uzyskanie zezwolenia oraz forma prawna spółki akcyjnej lub towarzystwa ubezpieczeń wzajemnych), jak i kapitałowe (minimalny kapitał zakładowy od 2,5 mln zł do 3,7 mln zł - w zależności od rodzaju wykonywanej działalności). Jednocześnie jedynym wyłączeniem od wyżej wymienionych wymogów jest możliwość prowadzenia działalności w formie małego towarzystwa ubezpieczeń wzajemnych (zastrzeżonego w zasadzie dla samorządów zawodowych) lub małej spółki akcyjnej. 
zarówno analizy: opisowe (o przeszłości), prognostyczne, jak i normatywne wykorzystuje modele do opisu optymalnych zachowań i działań. Określana jest również jako analityka na „skalę przemysłową”, gdyż polega na tworzeniu ogromnej liczby modeli przy zastosowaniu uczących się systemów (fabryka modeli oraz „linii montażowej danych”).

Big Data to termin stosowany do opisywania dużych zbiorów danych cyfrowych, charakteryzujących się $4 \mathrm{~V}$, a mianowicie dużą: objętością (volume); zawrotną szybkością ich generowania (velocity); wysoką różnorodnością (variety) oraz niepełną wiarygodnością (veracity). Ich przetwarzanie i analiza są trudne, ale jednocześnie niezwykle wartościowe, gdyż pozwalają na zdobycie nowych informacji lub wiedzy, wymagają jednak stosowania wcześniej nieznanych metod przetwarzania, a także „otwartych" umysłów ${ }^{33}$.

Źródłem danych może być zatem wszystko, przez co pojawiło się określenie internet wszechrzeczy (Internet of Everything, IoE), obejmujący: dane liczbowe, ludzi („dane resztkowe”), procesy, a także internet rzeczy (IoT) ${ }^{34}$. Termin „dane resztkowe" oznacza dane, które powstaja jako produkt uboczny działań i ruchu każdego człowieka $a^{35}$, a więc w internecie jest to liczba kliknięć, czas przeglądania określonych stron, wpisywane komentarze itd. Internet rzeczy definiuje się jako: ekosystem, $w$ którym przedmioty mogą komunikować się między sobą, za pośrednictwem człowieka lub bez jego udziału ${ }^{36}$. Koncepcję IoT stworzył w $1999 \mathrm{r}$. Kevin Ashton, by opisać system komunikacji świata materialnego z komputerami za pomocą wszechobecnych sensorów (czujników) ${ }^{37}$.

Istotnym aspektem analityki zaawansowanej jest wykorzystywanie metod eksploracji danych (data mining), wykorzystujących statystyki matematyczne oraz algorytmy maszynowego uczenia się. Eksploracja danych określana jest jako odkrywanie wiedzy w bazach danych (knowledge discovery in databases), a więc niejawnej, wcześniej nieznanej, nieuświadamianej, a potencjalnie użytecznej. Pozwala zatem na dowiedzenie się czegoś nowego o badanym wycinku rzeczywistości, co oznacza właśnie odkrywanie wiedzy, która wcześniej nie była dostrzegana, a co znakomicie wykorzystują fintechy w innowacjach produktów,

33 R. Milic-Czerniak, Analityka biznesowa 3.0 [w:] Współczesne wyzwania nauk społecznych i ekonomicznych, red. J. Żylińska, I. Przychocka, M. Filipowska-Tuthil, Uczelnia Techniczno-Handlowa, Warszawa 2016.

${ }^{34}$ J. Macaulay, L. Buckalew, G. Chung, Internet of Things in logistics, Report DHL/Cisco, 2015, www.dhl.com/DHLTrendReport_internet_of_things.pdf [dostęp: 30 czerwca 2018 r.].

35 V. Mayer-Schänberger, K. Cukier, BIG DATA. Rewolucja, która zmieni nasze myślenie, pracę i życie, MT Biznes, Warszawa 2017, s. 151.

${ }^{36}$ W. Kokot, P. Kolenda, Czym jest internet rzeczy [w:] Raport „Internet rzeczy w Polsce”, IAB Polska, SAS, Warszawa 2015.

37 K. Ashton, That 'Internet of Things', czerwiec, 2009, www.rfidjournal.com/articles/ view?4986. 
usług oraz obsługi klientów, wzbogacając doświadczenia klientów w użytkowaniu produktów finansowych.

Polskie fintechy zapytane o stosowane w ich produktach i usługach technologie wskazały przede wszystkim API (application programming interface, interfejs programowania aplikacji - 69\%), czyli jeden z podstawowych współczesnych mechanizmów komunikacyjnych, a następnie Intelligence Automation / Data Science (45\%) oraz Big Data (37\%, IoT 12\%). Co czwarty respondent wskazał także elektroniczną weryfikację tożsamości (eID), a następnie Cloud Computing (22\%). Blockchain, a więc technologię, która może zdominować w najbliższych latach rynek fintech, stosuje aktywnie $7 \%$ respondentów ${ }^{38}$.

\section{Karta płatnicza jako innowacyjny produkt bankowy}

W 2018 r. wydanych było na świecie 6,3 mld kart debetowych oraz 2,7 mld kart kredytowych, a do 2023 r. liczba ich ma wzrosnąć odpowiednio do 8,4 mld oraz 3,3 mld $^{39}$. European Payments Council (EPC) definiuje kartę płatniczą jako kartę, którą jej posiadacz może użyć w bankomacie do podjęcia gotówki albo do transakcji zapłaty w POS-ie (point-of-sale) ${ }^{40}$. Zgodnie natomiast $\mathrm{z}$ ustawą o usługach płatniczych karta płatnicza jest to karta, która uprawnia do wypłaty gotówki lub umożliwia złożenie zlecenia płatniczego za pośrednictwem akceptanta lub agenta rozliczeniowego, akceptowana przez akceptanta w celu otrzymania przez niego należnych mu środków ${ }^{41}$. Bankowa karta płatnicza jest zatem produktem elektronicznym, umożliwiającym zdalne wykorzystanie środków finansowych zgromadzonych na rachunku w banku lub udostępnionych w umowie kredytowej.

Wynalazek karty płatniczej zaliczyć można niewątpliwie do innowacji przełomowej, która wraz z dalszymi modyfikacjami zapoczątkowała całkowitą zmianę w sposobach płatności - najpierw głównie w dostępie do gotówki (z bankomatów), a następnie w eliminacji gotówki z transakcji płatniczych. W pracach Europejskiego Banku Centralnego karty płatnicze uważane są za jeden $\mathrm{z}$ trzech podstawowych instrumentów płatniczych (po przelewach i poleceniach zapłaty) ${ }^{42}$.

${ }^{38}$ Mapa polskiego FinTechu 2018, op. cit.

39 Advanced Payments Report 2018, Edgar, Dunn \& Company, http://edgardunn.com/ tag/advanced-payments-report/ [dostęp: 3 grudnia 2018 r.].

40 SEPA Cards Framework, Version 2.0, 8 March 2006, https://www.voeb.de/download/ sepa-anlage6.pdf [dostęp: 20 grudnia 2018 r.].

41 Art. 2 i 15a ustawy z 19 sierpnia 2011 r. o usługach płatniczych, Dz.U. nr 199 poz. 1175.

${ }^{42}$ Card Payments in Europe - a renewed focus on SEPA for cards, ECB, Frankfurt am Main 2014, s. 12, https://www.ecb.europa.eu/pub/pdf/other/cardpaymineu_renfoconsepaforcards201404en.pdf [dostęp: 3 grudnia 2018 r.]. 
W Polsce można mówić o dwóch istotnych instrumentach płatności bezgotówkowych: kartach płatniczych oraz przelewach, gdyż polecenia zapłaty są bardzo rzadko wykorzystywanym sposobem regulowania rachunków za usługi. Karty płatnicze mają natomiast coraz większy udział w strukturze płatności bezgotówkowych - podczas gdy w $2000 \mathrm{r}$. wynosił on tylko $11 \%$, w $2010 \mathrm{r}$. 36\%, to w 2017 r. zwiększył się już do 59\%, osiągając wyższy udział od liczby transakcji przelewem (wykres 1).

Polacy nie darzą zaufaniem poleceń zapłaty, których udział w transakcjach bezgotówkowych wynosił w 2017 r. zaledwie 0,4\% (w 2000 r. 0,2\%), podczas gdy średnio w państwach Unii Europejskiej stanowił aż 20\% ${ }^{43}$. Polecenie zapłaty jest szczególnie preferowane w Niemczech, gdzie wynosi prawie połowę transakcji bezgotówkowych (49\%), a także w Hiszpanii (29\%) oraz w Austrii (24\%). W krajach tych wdrożono jednak zmodyfikowaną wersję poleceń zapłaty, tzw. elektroniczne polecenie zapłaty (Elektronische Lastschriftverfahren), wykorzystywaną w sieci detalicznej. Podczas tej transakcji dane zgromadzone na karcie debetowej dają podstawę wystawienia przez sprzedawcę jednorazowego polecenia zapłaty, które jest autoryzowane przy POS-ie przez posiadacza karty (najczęściej poprzez złożenie podpisu) ${ }^{44}$.

Modyfikacja polecenia zapłaty wprowadzona w 2018 r. przez 11 banków w Polsce, polegająca na przeprowadzaniu transakcji pomiędzy stronami uczestniczącymi w systemie QLIPS powinna niewątpliwie wpłynąć na wzrost liczby transakcji polecenia zapłaty. Dostawca produktu lub usługi umieszcza informację o płatności w czasie rzeczywistym w systemie bankowości elektronicznej płatnika w bazie Invoobill 2.0, a płatnik zatwierdza płatność kliknięciem, bez konieczności wprowadzania do systemu informacji o zobowiązaniu czy też danych dostawcy ${ }^{45}$. Powyższe modyfikacje polecenia zapłaty pozwalają zatem zaakceptować transakcję płatnikowi, co usuwa jego wątpliwości przy korzystaniu z tej formy płatności, gdyż może każdorazowo podejmować decyzję o zapłaceniu, a do tego nie musi wypełniać formularzy (jak np. przy dokonywaniu przelewu).

Jeżeli chodzi o udział transakcji kartami płatniczymi w strukturze transakcji bezgotówkowych, to w Polsce był on w 2017 r. wyższy od średniego unijnego (59\% vs. 52\%). Najwyższy jest on natomiast w Danii (81\%),Wielkiej Brytanii oraz w Portugalii (po 70\%).

${ }_{43}$ Polecenie zapłaty jest instrumentem preferowanym do rozliczeń przez wierzycieli usług masowych, ponieważ daje im kontrolę nad spływem wierzytelności. Uwalnia również klientów od comiesięcznego pilnowania uiszczania rachunków za usługi o zmiennych kwotach (np. za czynsz, gaz, telefon, wodę).

${ }^{44}$ T. Philippon, The FinTech Opportunity March 2018, http://pages.stern.nyu. edu/ tphilipp/papers/FinTech.pdf [dostęp: 20 grudnia 2018 r.].

${ }^{45}$ K. Machowski, E. Kowalczyk, W. Kiciński, QLIPS: nie trać czasu na płatności!, Raport Specjalny - Płatności Bezgotówkowe, „Nowoczesny Bank Spółdzielczy” 2018, nr 11. 


\section{Wykres 1. Struktura transakcji bezgotówkowych w Polsce w roku 2000, 2010 oraz 2017

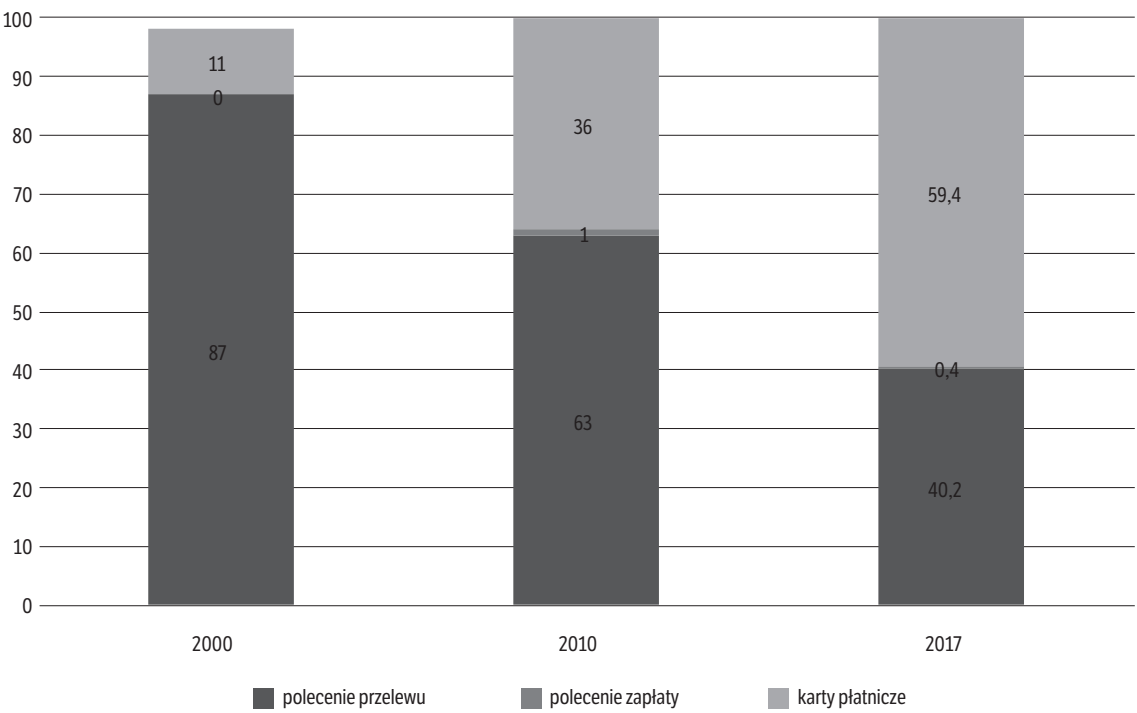

Źródło: na podstawie M. Polasik i in., Modelowanie wykorzystania metod płatności detalicznych na rynku polskim, NBP, „Materiały i Studia” 2012, z. 265, s. 9, oraz Payment statistics for 2017, ECB, Press Release, 14 September 2018, https://www.ecb.europa.eu/press/pr/stats/paysec/html/index.en.html [dostęp: 20 października 2018 r.].

Warto zwrócić uwagę również na kilka cech swoistych kart płatniczych jako produktu innowacyjnego, a przede wszystkim na fakt, że w proces wdrażania, modyfikacji i upowszechniania bankowych kart płatniczych zaangażowane są cztery podmioty, podczas gdy innowacje produktowe czy usługowe obejmują najczęściej dwa podmioty. Wynika to z procesu akceptacji transakcji kartami płatniczymi, w którym oprócz banku (prowadzi rachunek klienta, dostarcza kartę, ubezpiecza ją) i klienta jako posiadacza karty, biorą jeszcze udział: centrum rozliczeniowo-autoryzacyjne (działające najczęściej na licencji masowych systemów kart płatniczych VISA oraz MasterCard), a także akceptanci (najczęściej punkty handlowo-usługowe). Centrum autoryzacyjne współpracuje $\mathrm{z}$ akceptantami w zakresie procesu dokonywania płatności i jej autoryzacji. System czterostronny rozliczania transakcji przeprowadzanych bankowymi kartami płatniczymi jest systemem dominującym zarówno w Polsce, jak i w świecie.

Kolejną cechą bankowych kart płatniczych jest to, że ich używanie jest możliwe wyłącznie wtedy, gdy powstanie odpowiednia infrastruktura. Efektywne rozpowszechnianie kart płatniczych wymaga zatem równoczesnego rozwoju urządzeń umożliwiających ich używanie, takich jak bankomaty oraz terminale do transakcji bezgotówkowych czy też rozwiązań typu cash back, a więc moż- 
liwości pobrania gotówki w sklepie przy dokonywaniu płatności kartą. Banki są głównie odpowiedzialne za zakup tych urządzeń, instalację i bieżącą obsługę, a także za zasady ich udostępniania posiadaczom kart (własnym i obcym klientom).

\section{Udział fintechów w rozwoju innowacji kart płatniczych}

W procesie rozwoju innowacji karty płatniczej w Polsce można wyodrębnić trzy wyraźnie zaznaczające się etapy. W etapie pierwszym, trwającym prawie piętnaście lat (199146-2005) modyfikacje bankowych kart płatniczych polegały na rozszerzaniu grona ich posiadaczy (klienci indywidualni oraz instytucjonalni), a także na rozszerzaniu sposobów rozliczeń płatności kartami [obok kart debetowych i obciążeniowych pojawily się karty kredytowe oraz przedpłacone (pre-paid)]. Implementacja kart płatniczych skoncentrowana była zatem głównie na procesie dyfuzji kart, w który zaangażowane były głównie banki, przez co jego cykl trwał nie krócej niż w sektorze przemysłu.

Etap drugi (2006-2013) związany jest z rozpoczęciem wdrażania kart z mikroprocesorem (chipem, w standardzie EMV). Implementacja tej innowacji trwała relatywnie długo i na dobre rozpoczęła się dopiero po zawiązaniu konsorcjum EMV, a więc po jej akceptacji przez główne systemy wykorzystujące karty ${ }^{47}$. Powolna implementacja kart EMV w Polsce wynikała początkowo m.in. z wysokich kosztów związanych z przebudową infrastruktury technicznej i informatycznej oraz koniecznością wprowadzenia zmian prawnych związanych $\mathrm{z}$ funkcjonowaniem kart płatniczych w tym standardzie ${ }^{48}$.

W Polsce pod koniec 2017 r. w systemie EMV funkcjonowało 95\% kart płatniczych, 94\% terminali POS i 97\% bankomatów. Szczególne znaczenie miało na tym etapie również wdrożenie płatności zbliżeniowych - na koniec $2017 \mathrm{r}$. 80\% bankowych kart płatniczych umożliwiało dokonywanie płatności zbliżeniowych ${ }^{49}$.

${ }^{46}$ W Polsce pierwszą bankową kartę płatniczą wydał Bank Inicjatyw Gospodarczych (obecnie Bank Millenium) w maju 1991 r. Była to karta BIG VISA Business Card do użytku służbowego. Autoryzacja transakcji trwała ok. 30 minut. Slogan reklamowy karty „BIG VISA Business Card brzmiał „To karta nie dla każdego”, podkreślając jej elitarny charakter, co nie sprzyjało jej upowszechnianiu.

47 Skrót od nazwy trzech firm, tworzących konsorcjum (JCB, MasterCard, Visa), wspólnie sponsorujących globalny standard elektronicznych transakcji finansowych w odniesieniu do technicznych aspektów kart z chipem. SEPA Cards Framework, Version 2.0, op. cit.

${ }^{48}$ P. Opitek, Wpływ standardu EMV na nielegalne działania $z$ wykorzystaniem kart płatniczych w kontekście przestępstwa skimmingu, „Bezpieczny Bank” 2016, nr 1(62), s. 138.

49 Informacja o kartach płatniczych, NBP, Warszawa 2017, https://www.nbp.pl/systemplatniczy/karty/q_04_2017.pdf [dostęp: 27 sierpnia 2018 r.]. 
Karty z mikroprocesorem są przede wszystkim bezpieczniejsze (w 99\%) niż karty z paskiem magnetycznym, a ponadto mają większą pojemność i zdolność do przetwarzania informacji, np. mikroprocesor zapisuje każdą transakcję, umożliwiając jej późniejsze odtworzenie, może więc sam autoryzować transakcję, bez połączenia z bankiem, przez co jednocześnie ograniczają koszty telekomunikacyjne oraz skracają czas przeprowadzania transakcji, szczególnie przy rezygnacji $\mathrm{z}$ autoryzacji online dla wybranych typów transakcji (do $50 \mathrm{zł}$, a od 2019 r. do 100 zł). Stąd karty te mogą być wykorzystywane do tzw. mikropłatności, przy zakupach np. gazet w kioskach, opłat za parkowanie. Karty mikroprocesorowe mają o wiele większą pamięć niż karty z paskiem magnetycznym, dlatego można w nich zainstalować różne dodatkowe aplikacje, a więc tworzyć tzw. wielofunkcyjne instrumenty płatnicze, np. poprzez umieszczenie na mikroprocesorze karty z dwiema funkcjami - debetową i kredytową czy też rachunki w różnych walutach. Ponadto karty płatnicze nowej generacji umożliwiają tworzenie kart o wielorakim przeznaczeniu (np. z legitymacją studencką) ${ }^{50}$.

Etap trzeci (od 2014 r.) modyfikacji kart płatniczych rozpoczęło pojawienie się kart HCE w 2014 r. do płatności mobilnych, chociaż wdrożenie płatności mobilnych nastąpiło już w 2012 r., ale oparte było ono na technologii NFC (Near Field Communication). Wymagały one posiadania smartfonów wyposażonych w kartę (np. Visa) instalowaną na karcie SIM w telefonie, jako odrębną kartę płatniczą - ze swoim własnym numerem oraz kodem CVV2, dzięki czemu może być wykorzystywana również do płacenia w internecie ${ }^{51}$.

Płatności kartą HCE natomiast to płatności zbliżeniowe za pomocą telefonu komórkowego, które działają na tej samej zasadzie jak płatności zwykłymi kartami debetowymi, ale "pobiera” się je z „chmury” za pomocą aplikacji mobilnej banku. Banki powoli wycofują się z mobilnych płatności zbliżeniowych opierających się na kartach SIM (np. mBank, Raiffeisen), a wdrażają płatności nowszej generacji wykorzystujące „chmurę”.

Właśnie na trzecim etapie modyfikacji innowacji kart płatniczych zaobserwować można włączenie się fintechów - to one koncentrują się na przygotowywaniu wyspecjalizowanych aplikacji umożliwiających dokonywanie płatności bezgotówkowych, w tym kartami płatniczymi.

Intensyfikacja procesu infuzji spowodowała gwałtowny wzrost używalności kart - z państwa, w którym przypadało 1,42 transakcji bezgotówkowych kartą per capita w 2000 r., 22 transakcje w 2010 r. oraz 99 transakcji w 2017 r., Polska stała się państwem o jednym z najwyższych wskaźników liczby transakcji bezgotówkowych kartą płatniczą per capita. Porównując te wskaźniki ze średnimi

${ }^{50}$ Innowacje w kartach płatniczych, 23 maja 2017 r., https://www.najlepszekonto.pl/ innowacje-w-kartach-platniczych [dostęp: 23 sierpnia 2018 r.].

51 P. Utrata, Płatności mobilne Visa w ING Banku Śląskim, https://media.ingbank.pl/ informacje-prasowe/926/pr/289611/platnosci-mobilne-visa-w-ing-banku-slaskim [dostęp: 17 maja 2018 r.]. 
dla państw UE, gdzie w 2010 r. zarejestrowano 68 płatności bezgotówkowych oraz 122 w roku 2017, widać wyraźnie, że posiadacze kart płatniczych w Polsce zwiększyli czterokrotnie liczbę tych płatności, podczas gdy w UE wzrosła ona w tym okresie średnio o niecałą połowę ${ }^{52}$.

Przyśpieszony proces absorbcji kart płatniczych w drugiej dekadzie XXI wieku jest rezultatem z jednej strony udostępniania kart bezpieczniejszych, mniej czasochłonnych, wygodniejszych oraz polepszenia infrastruktury płatności, a z drugiej strony intensyfikowania różnego typu promocji (rezygnacja z pobierania opłat za karty przy dokonywaniu określonej liczby lub kwoty transakcji bezgotówkowych w miesiącu, wprowadzanie rabatów przy zakupach kartą $\mathrm{w}$ wybranych sklepach, bezpłatne ubezpieczenia transakcji kartami, a nawet obniżanie rat kredytowych za zakup na raty np. smartfonu).

W proces komunikacji z użytkownikami kart płatniczych włączone zostały także instytucje pozabankowe. Szczególnie efektywna w swoich działaniach jest powołana przez Związek Banków Polskich, Ministerstwo Przedsiębiorczości i Technologii, Visa oraz Mastercard w 2017 r. Fundacja Polska Bezgotówkowa. Jej celem jest podejmowanie działań w zakresie rozbudowy sieci akceptacji instrumentów płatniczych, upowszechniania i promocji obrotu bezgotówkowego, a także promocji innowacji technologicznych wspierających obrót bezgotówkowy w Polsce. Fundacja ta intensywnie wykorzystuje także reklamy społeczne do promowania obrotu bezgotówkowego ${ }^{53}$.

\section{Podsumowanie}

W Polsce funkcjonuje już blisko dwieście podmiotów sektora fintech, które obejmują wszystkie główne, znane na świecie segmenty tego rynku. Najliczniej reprezentowaną grupą są firmy wyspecjalizowane w obszarze płatności oraz finansowania. Wykorzystują one intensywnie najnowocześniejsze technologie (API, BD, sztuczną inteligencję, Cloud Computing itd.).

Krajobraz polskiego rynku finansowego jest dość szczególny - innowacje przełomowe i przyrostowe realizowane są zarówno w małych firmach fintech, jak i w dużych bankach tradycyjnych, które mają kompetencje umożliwiające generowanie innowacji we współpracy z bankami konkurencyjnymi lub też samoistnie. Dzięki tej współpracy polski system bankowy szybko zaadaptował technologie, które do tej pory raczkują w Stanach Zjednoczonych czy państwach Europy Zachodniej. Polska pod względem wdrożeń płatności bezstykowych

${ }^{52}$ Payment statistic for 2017, op. cit.

53 Startuje Program Wsparcia Obrotu Bezgotówkowego Polska Bezgotówkowa, http:// polskabezgotowkowa.pl/aktualnosci/startuje_program_wsparcia_obrotu_bezgotowkowego_polska_bezgotowkowa [dostęp: 25 października 2018 r.]. 
(kartowych, mobilnych), płatności typu pay-by-link czy sektorowego rozwiązania typu Blik znajduje się w technologicznej awangardzie europejskiej.

Istotny wpływ na rozwój działalności firm fintech w poszczególnych segmentach usług mają regulacje prawne - sprzyjają mu w segmencie płatności, ale znacznie ograniczają w sektorze pożyczek społecznościowych oraz ubezpieczeń.

Karta płatnicza stanowi nadal jeden z głównych fundamentów rynku obrotu bezgotówkowego w świecie globalnym, internetu, gwałtownego wzrostu liczby transakcji płatniczych oraz szybkiego obiegu informacji. Fenomenem rozwoju innowacyjnego karty płatniczej jest przy tym nie tylko to, że jest bezpieczniejsza, szybsza, wygodniejsza i nadal postrzegana jako innowacyjny instrument płatniczy, ale że umożliwia często budowanie zaufania do takich instrumentów bezgotówkowych jak polecenie zapłaty (np. w Niemczech), czy też w realizacji płatności internetowych bezpośrednich, a także pośrednich poprzez tworzenie e-wallet ${ }^{54}$ (np. Masterpass).

W gwałtownym wzroście modyfikacji, innowacji przyrostowych związanych z kartą płatniczą istotną rolę odgrywają firmy fintech, działające często we współpracy z bankami, wykorzystując ich bazę klientów, infrastrukturę płatniczą, zaufanie, a dostarczając m.in. aplikacje czy też umieszczając innowacyjne produkty na platformie wielowymiarowej. Sprzyja to nie tylko skracaniu cyklu dyfuzji innowacji, ale jeszcze bardziej przyśpiesza proces infuzji kart płatniczych - można go zaobserwować na rynku kart płatniczych w Polsce, a jeszcze bardziej na tworzących się dopiero rynkach finansowych, jak np. rynek chiński.

\section{Bibliografia}

Advanced Payments Report 2018, Edgar, Dunn \& Company, http://edgardunn.com/tag/ advanced-payments-report/.

Ashton K., That 'Internet of Things', czerwiec 2009, www.rfidjournal.com/articles/ view?4986.

Card Payments in Europe - a renewed focus on SEPA for cards, European Central Bank, Frankfurt am Main 2014, https://www.ecb.europa.eu/pub/pdf/other/cardpaymineu_renfoconsepaforcards201404en.pdf.

CEE FinTech Report, Deloitte 2016, https://itreseller.com.pl/rynek-fintech-technologie-dla-uslug-finansowych-w-europie-srodkowo-wschodniej-jest-wart-22-mld-euro-cee-fintech-report-deloitte/.

European Innovation Scoreboard 2018, European Union, Luxembourg 2018, https:// www.interregeurope.eu/policylearning/news/3806/european-innovation-scoreboard-2018/.

${ }^{54}$ Jest to „portmonetka internetowa” korzystna dla osób, które często dokonują płatności do firm za granicą lub wysyłają tam pieniądze. 
Fintech $w$ Polsce, bariery i szanse rozwoju, raport UW, http://fintechpoland.com/wp-content/uploads/2016/12/fintech_w_Polsce_bariery_i_szanse_rozwoju.pdf.

Forging the future. How financial institutions are embracing fintech to evolve and grow, KPMG, November 2017, https://assets.kpmg.com/content/dam/kpmg/xx/ pdf/2017/10/forging-the-future-global-fintech-study.pdf.

Frame W.S., White L.J., Empirical Studies of Financial Innovation: Lots of Talk, Little Action?, Federal Reserve of Atlanta, Working Paper 6/2002.

The Future of fintech and Banking. Digitally disrupted or reimagined?, Raport Accenture, https://bluemedia.pl/pressroom/raporty/future-fintech-and-banking-raport-accenture.

Gospodarowicz A., Bankowość elektroniczna. Istota i innowacje, C.H. Beck, Warszawa 2018.

Hagiu A., Altman E.J., Jak stworzyć platformę na bazie własnego produktu, „Harvard Business Review Polska” kwiecień 2018.

Harasim J., Współczesny rynek płatności detalicznych - specyfika, regulacje, innowacje, Uniwersytet Ekonomiczny, Katowice 2013.

Informacja o kartach płatniczych, NBP, Warszawa 2017, https://www.nbp.pl/systemplatniczy/karty/q_04_2017.pdf.

Innowacje w kartach płatniczych, https://www.najlepszekonto.pl/innowacje-w-kartach-platniczych.

Innovation in Retail Payments, Report of the Working Group on Innovation in Retail Payments, Committee on Payment and Settlement Systems, BIS, May 2012.

Jasiński A.H., Model procesowy innowacji: ramy teoretyczne [w:] Innowacje w zarzadzaniu, red. J. Skalik, A. Zabłocka-Kluczka, seria „Prace Naukowe Uniwersytetu Ekonomicznego we Wrocławiu", Wrocław 2013.

Kokot W., Kolenda P., Czym jest internet rzeczy? [w:] Raport „Internet rzeczy w Polsce”, IAB Polska, SAS, Warszawa 2015.

Kotler P., Marketing. Analiza. Planowanie. Wdrażanie i kontrola, Gebethner i S-ka, Warszawa 1994.

Kühner A., Was deutsche Institute von Banken im Ausland lernen können, „Bankmagazin" 2016, nr 6.

Leading Global Fintech Innovators, fintech100, Report KPMG, 2018, https://h2.vc/wp-content/uploads/2018/11/Fintech100-2018-Report_Final_22-11-18sm.pdf.

Macaulay J., Buckalew L., Chung G., Internet of Things in logistics, Report DHL/Cisco, 2015, www.dhl.com/DHLTrendReport_internet_of_things.pdf.

Machowski K., Kowalczyk E., Kiciński W., QLIPS: nie trać czasu na płatności! Raport Specjalny - Płatności Bezgotówkowe, „Nowoczesny Bank Spółdzielczy” 2018, nr 11. Mapa polskiego fintechu 2018, Cashless, Fundacja FinTech Poland, Accenture, https:// www.cashless.pl/system/uploads/ckeditor/attachments/1908/Mapa_Polskiego_Fintechu_2018.pdf.

Mayer-Schänberger V., Cukier K., BIG DATA. Rewolucja, która zmieni nasze myślenie, prace i życie, MT Biznes, Warszawa 2017. 
Milic-Czerniak R., Analityka biznesowa 3.0 [w:] Współczesne wyzwania nauk społecznych i ekonomicznych, red. J. Żylińska, I. Przychocka, M. Filipowska-Tuthil, Uczelnia Techniczno-Handlowa, Warszawa 2016.

Opitek P., Wpływ standardu EMV na nielegalne działania $z$ wykorzystaniem kart płatniczych w kontekście przestępstwa skimmingu, „Bezpieczny Bank” 2016, nr 1(62).

Payment statistics for 2017, ECB, Press Release, 14 September 2018, https://www.ecb. europa.eu/press/pr/stats/paysec/html/index.en.html.

Philippon T., The fintech Opportunity March 2018, http://pages.stern.nyu.edu/ tphilipp/ papers/fintech.pdf.

Polasik M. i in., Modelowanie wykorzystania metod płatności detalicznych na rynku polskim, NBP, „Materiały i Studia” 2012, z. 265.

Polskę ominął boom na pożyczki społecznościowe. W Chinach standardy pożyczania P2P nie nadążyly za popytem, https://prnews.pl/polske-ominal-boom-pozyczki-spolecznosciowe-chinach-standardy-pozyczania-p2p-nadazyly-popytem-438829.

Prahalad C.K., Ramaswamy V., Przyszłość konkurencji, PWE, Warszawa 2005.

Rogers E.M., Diffusion of innovations, Free Press Collier-Macmillan, New York 1983.

Revolut uzyskat europejska licencje bankowa, zaoferuje depozyty i pożyczki, https:// prnews.pl/revolut-uzyskal-europejska-licencje-bankowa-zaoferuje-depozyty- pozyczki-439481? smclient=fccada31 - ad96-11e6-8101-0cc47a1256ac\&utm source $=$ salesmanago\&utm_medium $=$ email\&utm_campaign $=n l t \_b n k \_p r n e w s p l$.

Schumpeter J., Teoria rozwoju gospodarczego, PWN, Warszawa 1960.

SEPA Cards Framework, Version 2.0, 8 March 2006, https://www.voeb.de/download/ sepa-anlage6.pdf.

Sound Practices. Implications of fintech developments for banks and bank supervisors, Basel Committee on Banking Supervision, February 2018, https://www.bis.org/bcbs/ publ/d431.pdf.

Startuje Program Wsparcia Obrotu Bezgotówkowego Polska Bezgotówkowa, http://polskabezgotowkowa.pl/aktualnosci/startuje_program_wsparcia_obrotu_bezgotowkowego_polska_bezgotowkowa.

Szpringer W., Nowe technologie a sektor finansowy. Fintech jako szansa i zagrożenie, Poltext, Warszawa 2017.

Świeszczak K., Zaufanie w świecie finansów w obliczu rozwoju technologii na przykładzie banków i sektora fintech, „Bezpieczny Bank” 2017, nr 2.

Top of Mind Survey 2017, KPMG, https://home.kpmg.com/xx/en/home/insights/2017/06/ top-of-mind-survey-2017.html.

Utrata P., Płatności mobilne Visa w ING Banku Śląskim, https://media.ingbank.pl/informacje-prasowe/926/pr/289611/platnosci-mobilne-visa-w-ing-banku-slaskim.

World fintech Report 2017, Capgemini \& LinkedIn \& Efma. 